DANIJELA TULJAK-SUBAN, Ph.D. ${ }^{1}$

(Corresponding author)

E-mail: danijela.tuljak@fpp.uni-lj.si

VALTER SUBAN, M.Sc. ${ }^{1}$

E-mail: valter.suban@fpp.uni-lj.si

${ }^{1}$ Faculty of Maritime Studies and Transport,

University of Ljubljana

Pot pomorščakov 4, 6320 Portorož, Slovenia
Transport and Sustainable Development Original Scientific Paper Submitted: 7 July 2021 Accepted: 13 Oct. 2021

\title{
RATES THE SHIPS MUST PAY TO DELIVER THE OIL SLUDGE AS AN INCENTIVE TO IMPROVE PORT WASTE GREEN LOGISTICS
}

\begin{abstract}
Vessels of the shipping industry produce sludge during the operation of the main engine, various types of auxiliary engines, and the handling of fuel oil on board ships. The sludge can be stored in special tanks and disposed of ashore or burned on board. In the European Union, according to the Port Reception Facilities Directive (EU) 2019/883, ships have to pay a port waste fee for the delivery of ship waste, which is calculated according to the size of the ship. Such an approach does not take into account the capacity of port green waste logistics. In this paper, the case of delivery of ship sludge to ports that are similar in terms of waste logistics capacity is analysed. It is presented as a mathematical game between ships and ports to improve green waste logistics and match the amount of oil sludge that can be discharged from ships to the capacity of ports. The goal of the game is to discourage free-riders, which can occur on both sides, between suppliers and ports. The waste rate can be used as a regulator and incentive that discourages sludge dumping when recycling is not feasible. A model evaluation is proposed using a numerical example.
\end{abstract}

\section{KEYWORDS}

game theory; sludge; free-rider problem; shipping industry; green port logistics; waste.

\section{INTRODUCTION}

Ports, of course, are the centres where maritime and land-based economic activities are linked. Maritime transport produces 13 times less pollutant emissions than road transport and 19 times less hydrocarbon-based emissions. Port areas are the most critical points of this system from an environmental point of view: water pollution from oil and wastewater discharges from ports and ships, exhaust gases air pollution from ship engines, water pollution from toxins and the movement of harmful organisms via ballast water and sediments in ballast water tanks. [1]

Ship operations produce a certain amount of waste oil, which is referred to as oil sludge. The production of oil sludge on board comes from various sources such as: fuel oil purifiers, lube oil purifiers, main engine scavenging drains, main engine stuffing boxes, sumps under oil engines, drainage from settling and service tanks, and several other miscellaneous sources as a result of main engine operation, operation of various types of auxiliary machinery, and fuel oil handling. This sludge is stored in various tanks in the engine room and can be disposed of ashore or burned on board. Dumping overboard a ship is illegal. Due to the high water content in the sludge, marine engineers avoid burning it on board and usually prefer to dispose of it ashore.

The aim of the paper is to match the amount of sludge unloaded by the ships to the capacity of the port in order to have a low-waste and environmentally friendly logistics.

The activities of the ship are supported by the main engine and various types of auxiliary machinery. When fuel oil is handled on board ships, oil sludge is produced, which is stored in special tanks and disposed of ashore or burned on board. For disposal ashore, all ports must be equipped with suitable reception facilities. Since the ship has to unload the sludge after a certain time and all ports are equipped with reception facilities, this results in a mathematical game between ships and ports in which the process of sludge disposal can be compared to a series of moves made by players in a strategic game. 
The game is based on a hierarchical structure in which some players have a privileged role over others, but still the reduction of the impact that the sludge has on the environment and the development of a stable green logistics can be achieved through coordination and cooperation of all the players of the game. Unfortunately, some players of the game, at any level of the hierarchy, do not actively contribute to the solution of the problem. This passive attitude is also a social dilemma and is called the free-rider problem. The most common tools used to mitigate the free-rider problem are sanctions in the form of economic punishment and social punishment combined with hostility $[2,3]$.

The proposed model can be used to define a legal incentive to improve green waste logistics of ports and ships. In addition, the model based on game theory encourages ports to take a more proactive stance by sharing capacities for sludge separation or energy-efficient incineration, which are also more sustainable, cost-effective, and encourage environmentally friendly behaviour.

\section{LITERATURE REVIEW}

According to the International Convention for the Prevention of Pollution from Ships (MARPOL) Annex I, Regulation 12 "every ship of 400 gross tonnage and above shall be fitted with a tank or tanks of sufficient capacity, having regard to the nature of the machinery and the length of the voyage, to contain the oil residues (sludge) which cannot otherwise be dealt with in accordance with the requirements of Annex I, such as those arising from the cleaning of fuel and lubricating oils and oil leakages from machinery spaces" [4].

"For ships not carrying ballast water in fuel oil tanks, the minimum sludge tank capacity $\left(\mathrm{V}_{1}\right)$ in $\mathrm{m}^{3}$ should be calculated as $\mathrm{V}_{1}=\mathrm{K}_{1} \cdot \mathrm{C} \cdot \mathrm{D}$, where: $\mathrm{K}_{1}$ is 0.015 for ships on which heavy fuel oil is purified for use in the main engine, or 0.005 for ships using diesel oil or heavy fuel oil which does not require purification before use, $\mathrm{C}$ is the daily fuel oil consumption $\left(\mathrm{m}^{3}\right)$, and $\mathrm{D}$ is the maximum travel time between ports where sludge can be discharged ashore (days). In the absence of precise data, a value of 30 days should be used" $[4,5]$.

However, the capacity of sludge tanks can be calculated based on other reasonable assumptions. The calculated capacity is a minimum sludge tank capacity. On actual ships, the capacity of the sludge $\operatorname{tank}(\mathrm{s})$ is about 3-4 times greater [6].
The number of sludge tanks varies from ship to ship. It depends on the shipyard, on the machinery in the engine room and the ship owner's 'requirements'. Some ships have a common sludge tank, while others have individual sludge tanks. All sludge tanks must comply with the flag state oil record book and each transfer must be recorded in the oil record book.

Ship size has the greatest impact on the volume of oily waste delivered. Other variables that affect the delivery of both types of waste are the characteristics of the ship and its route [7].

The European Maritime Safety Agency (EMSA) published an empirical analysis of estimated sludge waste volumes, drivers, and treatment methods. According to this study, the estimated amount of oily residues (sludge) is 0.01 to $0.03 \mathrm{~m}^{3}$ of sludge per tonne of heavy fuel oil (HFO) and between 0 and $0.01 \mathrm{~m}^{3}$ per tonne of marine gas oil (MGO). This depends on the type of fuel and fuel consumption. Evaporation can reduce the amount of sludge by up to $75 \%$, while on board combustion can reduce the amount of sludge by $99 \%$ or more [8].

The percentage of ships disposing of domestic and oil wastes varies widely. For example, about $15 \%$ of all ships calling at Antwerp dispose of sludge and bilge water [9]. There are far fewer requests for sludge disposal in other ports, as most liners are not required to dispose of sludge in every port and on every voyage. Therefore, most requests for this service occur in ports that accommodate ships after overseas voyages.

Based on international law, legislation from the European Union (EU) requires ships to take the waste they generate on their voyages to waste reception facilities in port and requires EU ports to provide such facilities for ships using the port. The collection of ship-generated waste while ensuring efficient maritime operations in ports is regulated by Directive (EU) 2019/883 of the European Parliament and of the Council on port reception facilities for ship-generated waste, repealing Directive 2000/59/ EC and amending Directive 2009/16/ EC and Directive 2010/65/EU [10].

Directive (EU) 2019/883 also regulates how charges are to be levied according to the 'polluter pays' principle. Each ship has to pay an indirect fee in proportion to its size. The indirect charge covers the administrative costs and a significant part of the direct operating costs, which must represent at least $30 \%$ of the total direct costs for the actual 
delivery of the waste in the previous year. The part of the costs not covered by the indirect fee shall be recovered, where appropriate, on the basis of the types and quantities of waste actually delivered by the ship [10]. In the long run, charges should match costs.

In Europe, the indirect charge is the most widely used. Mostly they are combined with direct charges. According to [11], $68 \%$ of the studied ports use a direct tariff to charge for the delivery of oily waste.

These legal instruments regulate the protection of the marine environment in relation to the management of ship-generated waste and cargo residues in the seaports of the European Union. Therefore, it is crucial to organise the reception of waste and sludge by harmonising the legal provisions and the existing system of environmental fees and updating the calculation criteria for these fees as well as the procedures applied in seaports of the European Union for the notification of ship-generated waste [12].

Ships intending to leave port must demonstrate sufficient storage capacity for oil sludge, defined as sufficient capacity to store the quantity when a ship leaves port plus the oil sludge it is expected to produce on its next voyage. This next voyage may be within the EU, outside the EU, or unknown. If the voyage is within the EU, the master may waive the discharge of sludge if at least $25 \%$ tank capacity remains in the destination port, while for ports outside the EU or unknown, this percentage is $75 \%$ in the current port [13].

In the next section, a new definition of waste rate based on the game theory approach is proposed to serve as a regulatory and incentive system to discourage the disposal of oil sludge when recycling is not feasible.

\section{METHODOLOGY}

As explained in the introduction, oil sludge disposal logistics can be defined as a two-stage mathematical game. The main objective of game theory is to compute an equilibrium strategy, which in this case is to improve green waste logistics $[14,15]$.

Games are classified as coalitional or competitive. In the first stage of games, the optimal strategy is generally defined by the Nash equilibrium, which is not always the most obvious solution (e.g. the Prisoner's Dilemma). Moreover, games can sometimes be defined as hierarchical models where some players have a privileged role, as in this paper [16].
The players in this game are successive ports within the same system, with similar green logistics capacities and ships calling at these ports. All ports are players that have comparable characteristics and are subject to similar legal roles. The same is true for ships. Ports can be considered leaders in the two-level game known as the Stackelberg Game. Ships are followers that compete in the game and respond to the leader's moves [17].

Free-riding is possible at both levels, as a port may choose not to go green, or a ship may choose to deliver sludge in such a port because the economic cost is reduced. The paper formulates the game without and with penalties at the leader or follower level to discourage free-riders as passive actors regarding the environment.

\subsection{Game between ports and ships without penalty}

Ports lead the two-stage game and all have appropriate sludge collection facilities as required. The problem is what to do with this waste. Oil sludge collected at the port can be incinerated, separated, or simply transported to an authorised company outside the port (see Figure 1). It is clear that these solutions are not equally sustainable for the environment.

Ports can work in perfect competition or in collaboration. In either case, they must solve a multi-objective optimisation problem defined on the set of nodes $V(G)$ of the graph $G$ consisting of ports where ships can discharge sludge.

The following notations will be used in the presented models:

$i \in V$ - vertex (ports) of the graph $G=G(V, E)$; $|V|=n$ is the total number of the ports in the system.

$v_{j} \quad$ - the ship, $1 \leq j \leq m$ and $m$ is the total number of ships in the system.

$x_{i j} \quad$ - the volume of sludge that ship $v_{j}$ is going to unload at port $i$. The ship is obligated to dispose sludge according to EMSA guidelines [13].

$V_{i} \quad$ - the maximum volume of sludge that can be received (accepted) at port $i$.

$x_{i j}^{I} \quad$ - the volume of sludge oil collected at port $i$ from ship $j$ that will be incinerated.

$x_{i j}^{S} \quad$ - the volume of sludge oil collected at port $i$ from ship $j$ that will be separated. 


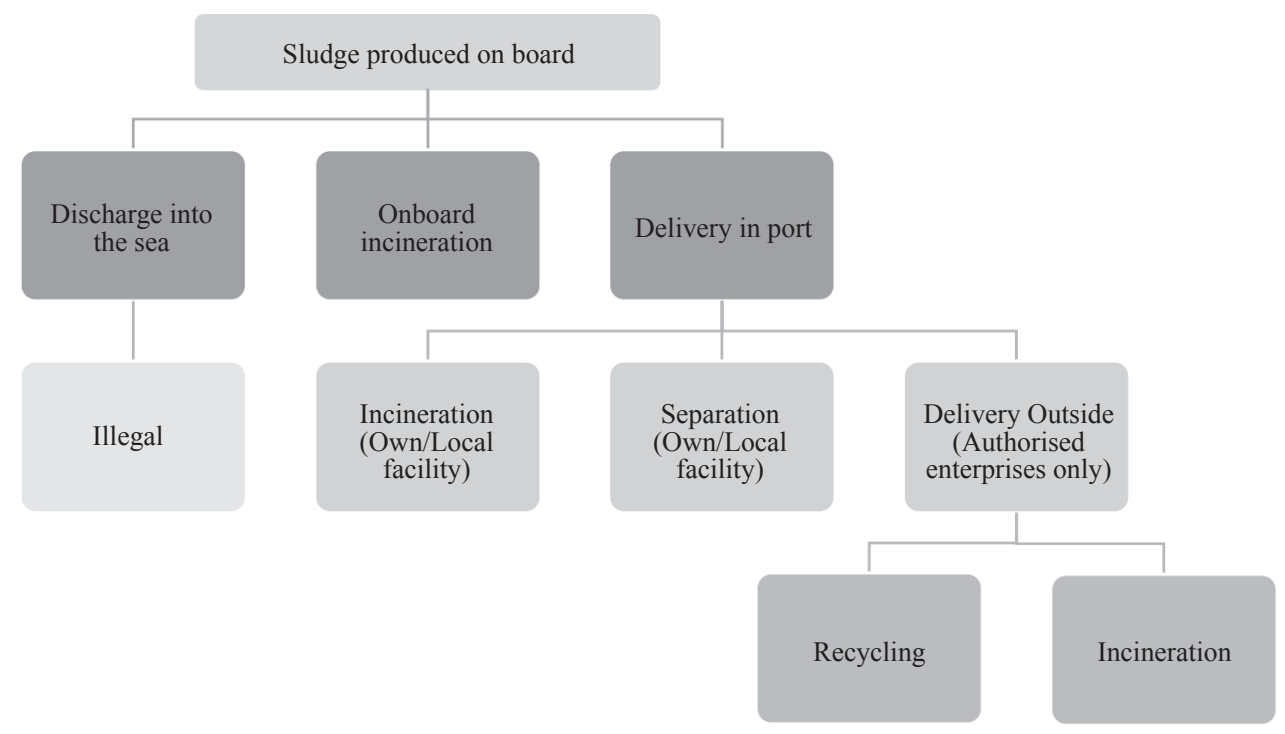

Figure 1 - Scheme of ship's sludge disposal

$x_{i j}^{O} \quad-$ the volume of sludge oil collected at port $i$ from ship $j$ that will be transported by the authorised company outside the port.

$c_{i j}^{I} \quad$ - the cost per unit of incineration of sludge within port $i$.

$c_{i j}^{S} \quad-$ the cost per unit of separation of sludge within port $i$.

$c_{i j}^{O} \quad$ - the transport cost (per unit) of sludge out side the port $i$, by the authorised company.

$c_{i j} \quad$ - the cost incurred by ship $v_{j}$ of unload volume $x_{i j}$ of sludge at port $i$. Only direct fees are considered since indirect are al ready included in the obligatory fee.

$L_{i k} \quad$ - variables that express the volume of oil sludge on the ship $v_{k}$ on arrival in the port (node) i. $L_{0 k}$ is the initial volume of sludge oil on ship $k$.

As explained before, the problem can be formulated in two ways: competition between the ports or cooperation between them.

\section{Perfect competition between ports}

In this case, the ports individually solve the optimisation problem:

$\min _{\alpha, \beta, \gamma} \sum_{j=1}^{m}\left(\alpha c_{i j}^{I} x_{i j}^{I}+\beta c_{i j}^{S} x_{i j}^{S}+\gamma c_{i j}^{O} x_{i j}^{O}\right)$

Subject to:

$\alpha+\beta+\gamma=1$ and $\alpha, \beta, \gamma \in[0,1]$

$\sum_{j=1}^{m}\left(x_{i j}^{I}+x_{i j}^{S}+x_{i j}^{O}\right) \leq V_{i}, \quad 1 \leq i \leq n$

$$
\begin{aligned}
& x_{i j}^{I}+x_{i j}^{S}+x_{i j}^{O}=x_{i j}, 1 \leq i \leq n, 1 \leq j \leq m \\
& L_{i j} \delta_{i k}-x_{i j}-L_{k j} \delta_{k i}=0,1 \leq i, k \leq n, 1 \leq j \leq m \\
& 0 \leq \delta_{i k}+\delta_{k i} \leq 2,1 \leq i, k \leq n
\end{aligned}
$$

The collaboration of neighbouring ports $i$ and $k$ is indicated by the collaboration indices $\delta_{i k}$ and $\delta_{k i}$ which respectively indicate the collaboration of port $i$ with port $k$ and vice versa. These values are associated with the capacity of the port to accept sludge oil.

In this way, each port tries to determine the optimal ratio between the volume of sludge oil that can be incinerated, separated, or transported outside the port. The proportions of these volumes are defined by the parameters $\alpha, \beta, \gamma$. The approach is purely economic, and the Nash equilibrium defines the port optimum.

In the second stage of the game, the ships as followers also formulate their individual multi-objective optimisation model:

$\min _{\alpha_{i}} \sum_{i=1}^{n} \alpha_{i} c_{i j} x_{i j}, \quad 1 \leq j \leq m$

Subject to:

$\sum_{i=1}^{n} \alpha_{i} x_{i j}=x_{i j}, \quad 1 \leq j \leq m$

$0 \leq \alpha_{i} \leq 1,1 \leq i \leq n$

$\sum_{j=1}^{m}\left(x_{i j}^{I}+x_{i j}^{S}+x_{i j}^{O}\right) \leq V_{i}, \quad 1 \leq i \leq n$ 
Ships aim to minimise the cost associated with unloading sludge oil, where $\alpha_{i}$ is the ratio of unloaded sludge in port $i$.

In this case, the bi-level game described is an example of the Stackelberg Leader-Followers Game [18]. The two levels of the game are connected by common variables $x_{i j}=x_{i j}^{I}+x_{i j}^{S}+x_{i j}^{O}$. The solution of the game is obtained by reducing the bi-level game to a single level game and replacing condition 7 by the Karush - Kuhn - Tucker condition [19].

\section{Perfect cooperation between ports}

In this case, the ports collaborate and try to define a common strategy for the disposal of the oil sludge. Therefore, all collaboration indices $\delta_{i k}$ are equal to 1 . The ports collaborate to solve the same optimisation problem as described in the previous section. In this case, Equations 1 and 2 are replaced by:

$$
\begin{aligned}
& \min _{\alpha_{i}, \beta_{i}, \gamma_{i j}} \sum_{i=1}^{m} \sum_{j=1}^{m}\left(\alpha_{i} c_{i j}^{I} x_{i j}^{I}+\beta_{i} c_{i j}^{S} x_{i j}^{S}+\gamma_{i} c_{i j}^{O} x_{i j}^{O}\right) \\
& \alpha_{i}+\beta_{i}+\gamma_{i}=1 \text { and } \alpha_{i}, \beta_{i}, \gamma_{i} \in[0,1], 1 \leq i \leq n
\end{aligned}
$$

The reduction of the bi-level game to a one-stage game is the same as in perfect competition with the appropriate modifications.

\subsection{Game between the ports and ships with a penalty at the leaders' level}

To improve the green logistics of sludge oil disposal, economic penalties can be introduced at ports (leaders' level) to further motivate ports to adopt sustainable behaviour. Penalties are added to improve the treatment of sludge oil in line with the new paradigm of circular economy [20]:

- separation of sludge oil to produce secondary raw materials, no penalty added,

- combustion of used oils to produce energy, add the penalty $P_{1}$, and

- thermal destruction of used oils (without the utilisation of produced energy) add the penalty $P_{2}$, $P_{2}>P_{1}$ since thermal destruction is the less sustainable.

In this case, the bi-level problem is formulated as in Section 2.1. Some corrections are made at the target functions in Equation 1 and 10.

$$
\begin{aligned}
& \min _{\alpha, \beta, \gamma} \sum_{j=1}^{m}\left(\alpha\left(1+P_{2}\right) c_{i j}^{I} x_{i j}^{I}+\beta c_{i j}^{S} x_{i j}^{S}+\gamma\left(1+P_{1}\right) c_{i j}^{O} x_{i j}^{O}\right) \\
& \min _{\alpha_{i}, \beta_{i}, \gamma_{i j}} \sum_{i=1}^{n} \sum_{j=1}^{m}\left(\alpha_{i}\left(1+P_{2}\right) c_{i j}^{I} x_{i j}^{I}+\beta_{i} c_{i j}^{S} x_{i j}^{S}+\gamma_{i}\left(1+P_{1}\right) c_{i j}^{O} x_{i j}^{O}\right)
\end{aligned}
$$

Those corrections also have an impact on the actions of followers (ships) that are forced to go green.

\subsection{Game between the ports and ships with the penalty at the followers' level}

In this case, penalties are added to followers that are not interested in implementing green logistics. Equation 7 is corrected as:

$$
\begin{aligned}
& \min _{\alpha_{i}} \sum_{i=1}^{n} \alpha_{i} c_{i j}\left(\alpha\left(1+P_{2}\right) c_{i j}^{I} x_{i j}^{I}+\beta c_{i j}^{S} x_{i j}^{S}+\gamma\left(1+P_{1}\right) c_{i j}^{O} x_{i j}^{O}\right), \\
& 1 \leq j \leq m
\end{aligned}
$$

Also in this case, corrections indirectly affected leaders, as ports that do not implement green logistics become unattractive, too expensive to unload sludge oil, and so these ports are not considered for sludge unloading.

\section{CASE STUDY AND DISCUSSION}

The proposed approach is tested using a case study consisting of data from three real ports in the European Union and two real ships calling at these ports along the same route. The route chosen is imaginary just to show how the model works. Some data on ports and ships are publicly available, while others come from the literature or are estimates by the authors. Since not all data are available, the authors have chosen to use generic names for ports and ships.

Table 1 shows the distances between the ports considered. Distances are in nautical miles (NM).

In the proposed numerical case study, the two ships headed for ports in succession: Port 1, Port 2, and Port 3. The authors assume that the two ships have similar size but adopt different navigation strategies in terms of speed and fuel consumption.

The initial volume of oil sludge on the ships $\left(L_{01}\right.$ and $L_{02}$ ) are assumed to be zero. Thus, only the numerical characteristics of the studied ships are proposed in Table 2, which are different and used in the studied game. The fuel consumption is computed using $[21,22]$.

Other data are not given, since the defined model and the cited regulations can be applied to any type of ship.

Table 1 -Distances between the ports

\begin{tabular}{||c|c|c|}
\hline \hline Origin port & Destination port & $\begin{array}{c}\text { Distance } \\
\text { (NM) }\end{array}$ \\
\hline \hline Port 1 & Port 2 & 3033 \\
\hline Port 2 & Port 3 & 600 \\
\hline Port 1 & Port 3 & 2740 \\
\hline
\end{tabular}


Table 2 - Ships characteristics

\begin{tabular}{||c|c|c|c|c||}
\hline \hline & $\begin{array}{c}\text { Speed } \\
{[\mathrm{kn}]}\end{array}$ & $\begin{array}{c}\text { Fuel consumption } \\
\text { per day }\left[\mathrm{m}^{3}\right]\end{array}$ & $\begin{array}{c}\text { Gross } \\
\text { tonnage }\end{array}$ & $\begin{array}{c}\text { Sludge } \\
\text { capacity } \\
{\left[\mathrm{m}^{3}\right]}\end{array}$ \\
\hline \hline Ship 1 & 20 & 80 & 9978 & 50 \\
\hline Ship 2 & 16 & 50 & 9912 & 30 \\
\hline
\end{tabular}

The authors also assume that the ships do not carry ballast water in fuel oil tanks, so the minimum sludge tank capacity is calculated in accordance with $[4,5]$ and is $36 \mathrm{~m}^{3}$ for Ship 1 and $22.5 \mathrm{~m}^{3}$ for Ship 2 .

Since the ships have more capacity than the minimum, a capacity of $50 \mathrm{~m}^{3}$ (49 tons) for Ship 1 and $30 \mathrm{~m}^{3}$ (29.4 tons) for Ship 2 is considered (see Table 2). A specific gravity of $0.98 \mathrm{~kg} / \mathrm{l}$ is used for conversion to tons.

Table 3 shows the computed sailing days of the voyages for each ship between the ports involved in the game and the sludge generated between the voyage stages.

In the first simulation of the game, perfect competition between ports is assumed. In this case, each port accepts sludge independently and has disposal costs resulting from an independent sludge acceptance policy. Ports accept sludge ac- cording to Equations 1-6 and directive [13], and the treatment of oil sludge is defined based on cost minimisation only.

In these ports, the cost incurred for the disposal of sludge by ships is $€ 77.20$ for one unit of sludge in Port 1, €27.50 for one unit of sludge in Port 2, and $€ 50.00$ for one unit of sludge in Port 3.

The charges are taken from the tariffs of three well-known EU ports. These are only the direct operating costs, while the indirect costs that a ship pays in any case (whether it discharges sludge or not) are not taken into account.

In this situation, the best economic strategy for the two ships is to discharge the sludge before reaching the limit quantity, which is $75 \%$ of the tank capacity (see the Introduction), in the port where the limit quantity is reached or in the first upstream port where the cost is lowest, according to Equations 7-9. Table 4 shows the sludge disposal charges for the collected quantity.

For Ship 1, the $3^{\text {rd }}$ voyage between Port 1 and Port 2 is critical because the vessel exceeds $75 \%$ of the sludge tank capacity during this voyage, so it would be obliged to dispose of the tank contents at a cost of $€ 2459.98$. However, according to Equations $7-9$, the optimal strategy is to discharge the sludge during the $2^{\text {nd }}$ voyage at Port 2 at a cost of $€ 646.66$.

Table 3 - Sailing days and sludge produced between ports

\begin{tabular}{|c|c|c|c|c|c|}
\hline \multicolumn{2}{|c|}{ Voyage } & \multicolumn{2}{|c|}{ Ship 1} & \multicolumn{2}{|c|}{ Ship 2} \\
\hline Origin port & Destination port & Sailing days & $\begin{array}{l}\text { Sludge produced } \\
\qquad\left[\mathrm{m}^{3}\right]\end{array}$ & Sailing days & $\begin{array}{l}\text { Sludge produced } \\
\qquad\left[\mathrm{m}^{3}\right]\end{array}$ \\
\hline Port 1 & Port 2 & 6.32 & 7.58 & 7.90 & 5.92 \\
\hline Port 2 & Port 3 & 1.25 & 1.50 & 1.56 & 1.17 \\
\hline Port 3 & Port 1 & 5.71 & 6.85 & 7.14 & 5.35 \\
\hline \multicolumn{2}{|c|}{ Total sludge on a cycle: } & 15.93 & & 12.45 & \\
\hline
\end{tabular}

Table 4 - Sludge disposal in perfect competition between ports

\begin{tabular}{|c|c|c|c|c|c|c|c|c|c|c|}
\hline & & \multicolumn{3}{|c|}{ Voyage 1} & \multicolumn{3}{|c|}{ Voyage 2} & \multicolumn{3}{|c|}{ Voyage 3} \\
\hline & & Port 1 & Port 2 & Port 3 & Port 1 & Port 2 & Port 3 & Port 1 & Port 2 & Port 3 \\
\hline \multirow{3}{*}{ 号 } & Sludge & 0 & 7.58 & 9.08 & 15.93 & 23.52 & 25.02 & 31.87 & 39.45 & 40.95 \\
\hline & $\begin{array}{l}\text { Tank capacity use } \\
\text { rate }\end{array}$ & 0 & 0.15 & 0.18 & 0.32 & 0.47 & 0.50 & 0.64 & 0.79 & 0.82 \\
\hline & Disposal costs $(€)$ & 0 & 208.52 & 454.13 & 1229.99 & 646.66 & 1250.75 & 2459.98 & 1084.81 & 2047.38 \\
\hline \multirow{3}{*}{ 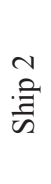 } & Sludge & 0 & 5.92 & 7.10 & 12.45 & 18.37 & 19.54 & 24.89 & 30.82 & 31.99 \\
\hline & $\begin{array}{l}\text { Tank capacity use } \\
\text { rate }\end{array}$ & 0 & 0.20 & 0.24 & 0.41 & 0.61 & 0.65 & 0.83 & 1.03 & 1.07 \\
\hline & Disposal costs $(€)$ & 0 & 162.91 & 354.79 & 960.93 & 505.21 & 977.15 & 1921.86 & 847.50 & 1599.51 \\
\hline
\end{tabular}


For Ship 2, the $2^{\text {nd }}$ voyage between Port 3 and Port 1 is critical because the ship exceeds $75 \%$ of the capacity of the sludge tank, so it would be obliged to discharge the sludge at a cost of $€ 977.15$, while according to Equations 7-9, the optimal strategy is to discharge the sludge in Port 2 during the $2^{\text {nd }}$ voyage at the minimum price of $€ 505.21$.

In this case, the best strategy for both ships is to discharge the sludge in the first upstream port with the lowest cost.

This strategy does not promote sustainable sludge logistics, as ports will only force the separation or incineration of sludge for energy if these methods are economically favourable to them.

The application of a "penalty-green tax" at the leader level can induce ships to favour ports that prefer separation or incineration for energy recovery from sludge, since the application of the penalty changes the best strategy for the ship, which in this case disposes of the sludge in the first upstream port with the lowest cost, which is also the one with the most sustainable disposal method.

In this case, joint collection of the sludge is also more complicated.

In the second game simulation, perfect cooperation between ports is assumed. In this case, all ports cooperate and have the same disposal costs, which are expressed by the same fees in all ports. In the numerical example, $€ 52.00$ is used as the average value of the costs in the case of perfect competition. This leads to the two ships deciding to unload the sludge when it reaches the limit quantity, superseding $75 \%$ of the tank capacity. Table 5 shows the sludge disposal charges for the collected quantity.
For Ship 1, the $3^{\text {rd }}$ voyage between Port 1 and Port 2 is critical because the ship exceeds $75 \%$ of the tank capacity during this period, so it would be obliged to dispose of the tank contents at a cost of $€ 1656.98$, which is also the optimal strategy according to Equations 7-9.

For Ship 2, the $2^{\text {nd }}$ voyage between Port 3 and Port 1 is critical, where the ship will exceed $75 \%$ of the sludge tank capacity, so it would be obliged to dispose of the sludge at a cost of $€ 1016.23$, which is the optimal strategy according to Equations 7-9.

This strategy does not promote sustainable sludge logistics because port cooperation forces joint collection of sludge, but not separation or incineration of sludge for energy. The application of a "penalty-green tax" at the leader level does not lead to a win-win effect in this case, as the ports cooperate and the penalty is applied to all.

The application of a "penalty-green tax" at the follower level may induce ships to favour those ports that prefer the separation or incineration of sludge for energy production, since according to Equations 7-9 the economically optimal strategy is also the most sustainable.

The application of a penalty at the follower level puts ports in competition and thus encourages sustainable behaviour in sludge disposal.

\section{CONCLUSIONS}

In the paper, the authors analyse the process of sewage sludge delivery to ports in order to increase the sustainability of prices. Considered are mainly the environmental and economic pillars; the social pillar is not directly considered, but it becomes clear that an effective disposal process that preserves the environment at a reasonable cost positively affects

Table 5 - Sludge disposal in perfect cooperation between ports

\begin{tabular}{|c|c|c|c|c|c|c|c|c|c|c|}
\hline & & \multicolumn{3}{|c|}{ Voyage 1} & \multicolumn{3}{|c|}{ Voyage 2} & \multicolumn{3}{|c|}{ Voyage 3} \\
\hline & & Port 1 & Port 2 & Port 3 & Port 1 & Port 2 & Port 3 & Port 1 & Port 2 & Port 3 \\
\hline \multirow{3}{*}{$\vec{\sharp}$} & Sludge & 0 & 7.58 & 9.08 & 15.93 & 23.52 & 25.02 & 31.87 & 39.45 & 40.95 \\
\hline & $\begin{array}{l}\text { Rate of tank } \\
\text { capacity use }\end{array}$ & 0 & 0.15 & 0.18 & 0.32 & 0.47 & 0.50 & 0.64 & 0.79 & 0.82 \\
\hline & Disposal costs $(€)$ & 0 & 394.29 & 472.29 & 828.49 & 1222.78 & 1300.78 & 1656.98 & 2051.27 & 2129.27 \\
\hline \multirow{3}{*}{ 离 } & Sludge & 0 & 5.92 & 7.10 & 12.45 & 18.37 & 19.54 & 24.89 & 30.82 & 31.99 \\
\hline & $\begin{array}{l}\text { Rate of tank } \\
\text { capacity use }\end{array}$ & 0 & 0.20 & 0.24 & 0.41 & 0.61 & 0.65 & 0.83 & 1.03 & 1.07 \\
\hline & Disposal costs $(€)$ & 0 & 308.04 & 368.98 & 647.26 & 955.30 & 1016.23 & 1294.52 & 1602.55 & 1663.49 \\
\hline
\end{tabular}


the quality of life, as it is a step towards reducing environmental impact and improving the recycling of materials.

According to [23], there are several ways to encourage environmentally friendly behaviour. These include incentives for the shipping industry to achieve greener ship operations and reduce or limit the negative impacts of maritime transport. The payback period of investments in green technologies can also be shortened by economic incentives from environmental levies.

During the literature search, the authors did not find any articles directly dealing with sludge disposal to define the best green approaches. Only [6], [1], and [9] examine the bilge-water treatment system and waste reception at the port from a technical perspective. There are no articles that use operational research methods such as game theory to define new sustainable sludge disposal strategies. On the other hand, the European Community pays more attention to port reception facilities for marine waste delivery through many documents.

Based on existing EU and IMO normatives, the authors define a two-stage game in which ports "play" as leaders and ships as followers to define an economically optimal sludge disposal strategy.

A numerical example is used to show that passive behaviour (free-riders) in terms of environmental sustainability can occur on both sides, between ships and ports. Both behave passively in terms of increasing environmental sludge disposal, as the economic aspect (cost) is still the most important factor.

In the article, the authors propose to introduce penalties (green taxes) that discourage free-riders and promote green sludge logistics.

The proposed model, as the first in the field of defining a sustainable ship sludge disposal strategy, needs additional testing using real data, and a larger number of ships with different characteristics and a larger number of ports. The model can also be extended outside the European Union, taking into account the regulations in force in these areas. The costs and tariffs used in the method also need to be defined in more detail to include other requirements in the proposed model.

Taking into account what has been said, future research could focus on defining a large real dataset (data on sludge incinerated on board, quantities accepted by ports and their shares) and strive to apply the proposed method in real cases in a user-friendly way. To this purpose, the Blockchain could be used to record transactions and build trust between ports and ships.

The proposed model can also be used to define the optimal unloading point (port). Extended to include other factors, it can be a good starting point for further research, especially since, as mentioned, there are not so many published operational research articles in this area.

The model can also be used as a basis for economic strategies. As the proposed strategy encourages all players in the game (ports and ships) to take a more active stance to choose the most efficient path to a greener world. Shared capacities for sludge separation or energy-efficient incineration will also be more sustainable and cost-effective.

\author{
Dr. DANIJELA TULJAK-SUBAN ${ }^{1}$ \\ (Dopisni avtor) \\ E-mail: danijela.tuljak@fpp.uni-lj.si \\ Mag. VALTER SUBAN ${ }^{1}$ \\ E-mail: valter.suban@fpp.uni-lj.si \\ ${ }^{1}$ Fakulteta za pomorstvo in promet, \\ Univerza v Ljubljani \\ Pot pomorščakov 4, 6320 Portorož, Slovenija
}

\section{CENE, KI JIH MORAJO PLAČATI LADJE ZA ODDAJO ODPADNIH OLJ, KOT SPODBUDA ZA IZBOLJŠANJE PRISTANIŠKE ZELENE LOGISTIKE ODPADKOV}

\section{POVZETEK}

Odpadna olja na ladji nastajajo med delovanjem glavnega motorja, različnih vrst pomožnih strojev in pri rokovanju z gorivom na ladji. Ta olja se hranijo v posebnih rezervoarjih in nato izkrcajo v pristanišču ali pa zažgejo na ladji. V Evropski uniji morajo, v skladu z Direktivo o pristaniških sprejemnih zmogljivostih za oddajo odpadkov z ladij (EU) 2019/883 ladje plačati pristojbino za oddajo ladijskih odpadkov v pristanišču, glede na velikost ladje. Tak pristop ne upošteva zmogljivosti pristaniške zelene logistike odpadkov. V tem članku je analiziran primer oddaje ladijskih odpadnih olj v pristaniščih, ki so si podobna glede logističnih zmogljivosti odpadkov. Postopek je prikazan kot matematična igra med ladjami in pristanišči za izboljšanje zelene logistike odpadkov in določanje količine odpadnih olj, ki jih oddajajo ladje, glede na zmogljivost pristanišč. Cilj igre je odvračati »free riderje", ki se lahko pojavijo na obeh straneh, med ladjami ali pristanišči. Cena oddaje odpadnih olj se lahko uporablja kot regulator in spodbuda, ki preprečuje nelegalne izpuste odpadnega olja, kadar recikliranje ni izvedljivo. Evalvacija modela je prikazana z uporabo numeričnega primera. 


\section{KLJUČNE BESEDE}

teorija iger; odpadna olja; problem »free riderjev«; pomorstvo; zelena pristaniška logistika; odpadki.

\section{REFERENCES}

[1] Quynh LX, Hens L, Stoyanov S. Water management in the framework of environmental management systems in Bulgarian seaports. Physics and Chemistry of the Earth, Parts A/B/C. 2011;36(5): 141-9. DOI: 10.1016/ j.pce.2010.05.004

[2] Corchón L. Two Stage Games. In: Corchón L, editor. Theories of Imperfectly Competitive Markets. Berlin, Heidelberg: Springer Berlin Heidelberg; 1996. p. 124-63.

[3] Assis MRM, Bittencourt LF. MultiCloud Tournament: A cloud federation approach to prevent Free-Riders by encouraging resource sharing. Journal of Network and Computer Applications. 2020;166: 102694. DOI: 10.1016/j.jnca.2020.102694

[4] MARPOL. Consolidated edition 2017. Resolution MEPC.187(59); 2017.

[5] MARPOL. Unified interpretations of regulations 1.24, 12, 27 and 28.3.3 of MARPOL Annex I; 2016.

[6] Wiewiora A, Listewnik J. Integrated bilge water treatment system. Journal of Machine Construction and Maintenance. 2007(3): 223-30.

[7] Pérez I, González MM, Jiménez JL. Size matters? Evaluating the drivers of waste from ships at ports in Europe. Transportation Research Part D: Transport and Environment. 2017;57: 403-12. DOI: 10.1016/j.trd.2017.10.009

[8] Nelissen D, Faber J. The Management of Ship-Generated Waste On-board Ships. CE Delft; 2017.

[9] De Langen PW, Nijdam MN. Charging systems for waste reception facilities in ports and the level playing field: A case from North-West Europe. Coast Manage. 2007;36(1): 109-24. DOI: 10.1080/08920750701682064

[10] EU-Commission. Directive on port reception facilities for the delivery of waste from ships. 883. EU2019.

[11] EMSA. Study on the Delivery of Ship-Generated Waste and Cargo Residues to Port Reception Facilities in EU Ports. EMSA; 2012.

[12] Deja A. Organisation of the reception of ship-generated wastes and cargo residues illustrated by selected examples of European Union seaports. Scientific Journals, Maritime University of Szczecin. 2013;33(105): 16-21.

[13] EMSA. Technical Recommendations on the Implementation of Directive 2000/59/EC on Port Reception Facilities. EMSA; 2016.

[14] Turocy TL, Stengel Bv. Game Theory. In: Bidgoli H, editor. Encyclopedia of Information Systems. New York: Elsevier; 2003. p. 403-20.

[15] Rasmusen E. Games and Information: An Introduction to Game Theory. Wiley-Blackwell; 2006.

[16] Tuljak-Suban D. Competition or cooperation in a hub and spoke-shipping network: The case of the North Adriatic container terminals. Transport. 2018;33(2): 429-36. DOI: $10.3846 / 16484142.2016 .1261368$

[17] Naima S, Odd IL. Container terminal concessions: A game theory application to the case of the ports of Pakistan. Maritime Economics \& Logistics. 2010;12(3): 237 62. DOI: $10.1057 / \mathrm{mel} .2010 .8$

[18] Nie P-Y. Dynamic discrete-time multi-leader-follower games with leaders in turn. Computers \& Mathematics with Applications. 2011;61(8): 2039-43. DOI: 10.1016/ j.nahs.2006.02.001

[19] Chong EKP, Zak SH. An Introduction to Optimization. Wiley; 2013.

[20] EU-Commission. Communication from the Commission to the European Parliament, the Council, the European Economic and Social Committee and the Committee of the Regions; 2015.

[21] Notteboom TE, Vernimmen B. The effect of high fuel costs on liner service configuration in container shipping. Journal of Transport Geography. 2009;17(5): 325-37. DOI: 10.1016/j.jtrangeo.2008.05.003

[22] Notteboom T, Cariou P, editors. Fuel surcharge practices of container shipping lines: Is it about cost recovery or revenue making. Proceedings of the 2009 International Association of Maritime Economists (IAME) Conference, 24-26 June 2009, Copenhagen, Denmark; 2009.

[23] EU-Commission. Study on Differentiated Port Infrastructure Charges to Promote Environmentally Friendly Maritime Transport Activities and Sustainable Transportation; 2017. 